\title{
Penyusunan Laporan Keuangan UMKM di Desa Jambu Kabupaten Sumenep dalam Meningkatkan Akuntabilitas Pelaporan Keuangan
}

\author{
Moh. Faisol*1, Aprilya Dwi Yandari², Very Andrianingsih ${ }^{3}$
}

\author{
1,2Akuntansi, Fakultas Ekonomi dan Bisnis, Universitas Wiraraja, Indonesia \\ ${ }^{3}$ Manajemen, Fakultas Ekonomi dan Bisnis, Universitas Wiraraja, Indonesia \\ *e-mail: $\underline{\text { aisol114@wiraraja.ac.id }}^{1}{ }_{\text {aprilya@wiraraja.ac.id }}^{2}{ }^{\text {veryandrianingsih@wiraraja.ac.id }}{ }^{3}$
}

\begin{abstract}
Abstrak
Akuntansi adalah proses pencatatan, penggolongan, pengikhtisaran, serta membuat laporan transaksi pada suatu usaha kecil, menengah, maupun besar. Secara umum UMKM merupakan usaha yang kurang memiliki tata kelola yang baik, sehingga para pelaku mengalami kesulitan dalam menentukan hasil yang mereka capai. UMKM yang berada di desa Jambu Kecamatan Lenteng saat ini berada dibawah pengawasan dinas UMKM Kabupaten Sumenep. Namun setelah tim melakukan wawancara dan survey pada pelaku UMKM di Desa Jambu, hampir semua UMKM tidak membuat laporan keuangan dasar. Para pelaku hanya membuat catatan keuangan tentang uang masuk dan keluar saja, namun tidak mampu menjelaskan perkembangan keuangan usahanya. Oleh karena itu, tim memberikan sosialisasi dan pelatihan terkait pentingnya pelaku UMKM tersebut membuat dan memiliki laporan keuangan dasar. Metode pada pengabdian dilakukan dengan cara analisis situsasi atau survey, interview, sosialisasi dan pelatihan, dan metode akhir pengumpulan laporan keuangan yang sudah diberikan pembinaan oleh tim. Hasil pada kegiatan ini pada daerah setempat yaitu dengan adanya sosialisasi serta pelatihan tersebut para peserta sangat memiliki pemahaman terkait dengan proses pencatatan atau dasar akuntansi dalam menyusun suatu laporan keuangan yang baik. Manfaat dari kegiatan tersebut bagi pemilik atau perwakilan dari UMKM di Desa Jambu mampu memberikan pengetahuan serta tanggung jawab atas financial statement tersebut.
\end{abstract}

Kata Kunci: Akuntabilitas, Laporan Keuangan, UMKM

\begin{abstract}
Accounting is the process of recording, classifying, summarizing, and making transaction reports on a small, medium, or large business. In general, MSMEs are businesses that lack good governance, so the actors have difficulty determining the results they achieve. MSMEs located in Jambu Village, Lenteng Subdistrict are currently under the supervision of the MSME Service of Sumenep Regency. However, after the team conducted interviews and surveys on MSME actors in Jambu Village, almost all MSMEs did not make basic financial reports. The perpetrators only made financial records of incoming and outgoing money, but were unable to explain the financial development of their business. Therefore, the team provided socialization and training related to the importance of MSME actors making and having basic financial reports. The method of service is carried out by means of situational analysis or surveys, interviews, socialization and training, and the final method of collecting financial reports that have been given guidance by the team. The result of this activity in the local area is that with the socialization and training the participants have a very good understanding of the recording process or basic accounting in preparing a good financial report. The benefits of these activities for owners or representatives of SMEs in Jambu Village are able to provide knowledge and responsibility for the financial statement.
\end{abstract}

Keywords: Accountability, Financial Reports, MSMEs

\section{PENDAHULUAN}

Griffin dan Ebert (2007) mengungkapkan suatu perbedaan diantara kewirausahaan dan bisnis kecil. Dimana seseorang akan disebut wirausahawan ketika mereka mau menanggung risiko kepemilikan usahanya dengan melakukan pertumbuhan dan ekspansi sebagai tujuan utama. Namun jika pada pemilik usaha bisnis kecil maka ia memiliki ciri sebagai usahawan namun beberapa dari mereka tidak memiliki keinginan untuk memperluas usaha bisnisnya. Suatu keberhasilan seorang wirausaha yaitu dengan tidak ditentukan hanya dari satu factor saja namun ia akan melihat suatu kondisi lokasi yang sangat memungkinkan strategis atau bahkan dengan sumber modal yang cukup memadai melainkan dengan menentukan suatu kemampuan 
yang nantinya menunjukkan kemampuan manajemen yang baik dalam mengelola suatu usaha tersebut.

Usaha Kecil Menengah (UKM) adalah suatu usaha yang dapat berperan serta memiliki fungsi sebagai hal pengaman yang baik dalam menyediakan alternatif kegiatan usaha produktif, alternatif penyaluran kredit, maupun dalam hal penyerapan tenaga kerja. UKM saat ini dikategorikan sebagai penyelamat perekonomian Negara Indonesia di masa krisis periode 19992000. Adanya Usaha Kecil Menengah di Indonesia di saat itu tidak mengalami kebangkrutan atau krisis sehingga perekonomian Negara Indonesia mampu berjalan. Jika kita lihat dari total pekerja Negara Indonesia yang mencapai 110 juta orang, maka \pm 107 juta orang dikategorikan sebagai pelaku struktur Usaha Mikro, Kecil, dan Menengah atau UMKM. Hal tersebut dapat menunjukkan orang yang bekerja sebagai UMKM mencapai sekitar 97,3\%. Sehingga hanya 2,7\% pekerja dengan jumlah sekitar 3 juta orang yang bekerja pada perusahaan-perusahaan atau korporasi besar.

Adanya perkembangan UMKM tersebut maka hal teserbut perlu dilakukan suatu upaya dalam mendukung ekonomi kreatif, dikarenakan adanya persaiangan yang cukup ketat. Oleh karena itu, proses pembukuan yang belum secara rapi tertata dengan baik maka pelaku UMKM sangat sulit untuk dapat menentukan hasil usaha yang mereka peroleh. Hal tersebut dikarenakan para pelaku UMKM belum memahami dalam menentukan harga pokok produksi, sehingga mereka jika menentukan harga jualnya hanya berdasarkan persaingan di pasar bukan dengan cara melakukan perhitungan secara system akuntansi keuangan. Oleh karena itu, berdasarkan permasalahan yang telah dijelaskan diatas, maka diperlukannya para pelaku UMKM mempelajari proses akuntansi keuangan yang nantinya para pelaku dapat melakukan kegiatan usahanya dengan melakukan persaingan yang baik dan dapat menentukan hasil laba yang mereka peroleh. Adanya proses pembukuan yang secara baik akan membuat para pelaku UMKM nantinya akan mudah untuk memperoleh sumber dana dari berbagai pihak ketiga, seperti pihak kreditur.

Permasalahan yang banyak dihadapi oleh para pelaku UMKM di Kecamatan Lenteng khususnya pada Desa Jambu adalah kurangnya pemahaman dalam proses pembukuan secara baik. Selain itu, para pelaku UMKM di Desa Jambu Kecamatan Lenteng kurang memahami dalam menentukan suatu harga pokok produksi. Sehingga tujuan pentingnya pada kegiatan ini dapat membantu mereka menentukan harga jual barang atau produknya hanya dengan melihat system persaingan yang ada di marketnya bukan dengan melakukan perhitungan secara system akuntansi keuangan.

\section{METODE}

Bagian ini menjelaskan metode yang akan digunakan dalam pelaksanaan Pengabdian kepada Masyarakat. Agar nantinya dapat memaksimalkan hasil dan meningkatkan pemahaman peserta, maka langkah kerja yang nantinya dilakukan pada sosialisai dan pelatiham pembuatan laporan keuangan dasar bagi para UMKM di Desa Jambu Kecamatan Lenteng sebagai berikut:

1. Pada tahap awal tim melakukan survey pada tempat pengabdian dan perijinan kerja sama pelaksanaan progam pengabdian kepada masyarakat dengan mendatangi Kantor Kepala Deja Jambu Kecamatan Lenteng. Kami meminta kesediaan untuk menerima kami untuk memberikan bantuan sosialisasi dan pelatihan pembuatan laporan keuangan dasar UMKM.

2. Pra research kami lakukan dengan menginterview Kepala Desa Jambu dan membuat survei terhadap para UMKM. Hasil survei menjelaskan bahwa para UMKM tersebut sebagian besar belum membuat laporan keuangan dan sebagian kecil membuat laporan uang masuk dan keluar saja.

3. Pada saat proses pelaksanaan melakukan pengabdian kepada para UMKM yang dibina di Desa Jambu, tim melakukan sosialisasi terkait dengan betapa pentingnya pembuatan laporan keuangan dasar. Selanjutnya akan diberikan pelatihan pembuatan laporan keuangan dasar hingga akhirnya diberikan pendampingan pembuatan laporan keuangan masing 
masing usahanya. Selain itu juga tim memberikan peluang kepada pelaku usaha untuk mendampingi jika para pelaku merasa kurang paham akan materi yang diberikan.

4. Pada Tahap akhir, mitra UMKM binaan harus mampu memberikan laporan keuangan usaha masing-masing untuk dapat menunjukkan bahwa hasil pelatihan yang telah diadakan tim dapat berguna.

\section{HASIL DAN PEMBAHASAN}

Pelaksanaan rangkaian program pengabdian kepada masyarakat yang dilaksanakan dibalai desa Jambu Kecamatan Lenteng Kabupaten Sumenep, koordinasi awal dilakukan pada Bulan Agustus, tepatnya tanggal 09 Agustus 2021 di desa Jambu yang mana desa tersebut merupakan salah satu unit usaha UMKM yang diarahkan oleh kecamatan dikarenakan masih kurangnya unit usaha yang baik dan berkembang. Sebelum pengabdian dilakukan, para peneliti mencoba melakukan wawancara dan survey lapangan terkait pemetaan desa yang memiliki UMKM namun pengelolaan keuangannya masih kurang berjalan dengan baik.

Kegiatan koordinasi pada proses awal tersebut dihadiri oleh PJ, Kepala Desa, dan beberapa unit usaha mikro yang ada pada desa setempat. Ketika tim melakukan koordinasi tersebut, para pelaku usaha dan aparat desa menjelaskan permasalahan yang dihadapi dalam kegiatan bisnis yang ada. Koordinasi tersebut menunjukkan bahwasanya pelaku UMKM di Desa Kabupaten Sumenep belum membuat laporan keuangan yang sederhan yang mana para pelaku usaha hanya saja membuat catatan terkait dengan pengeluaran dan pemasukan. Sehingga selanjutnya berdasarkan hasil koordinasi awal tersebut maka terjadi suatu kesepakatan terkait dengan adanya pelaksanaan kegiatan pengabdian yang berupa pelatihan penyusunan laporan keuangan UMKM.

Kegiatan pengabdian tersebut dilaksanakan selama bulan Agustus sampai dengan September 2021. Proses pelatihan terkait dengan pencatatan dan penyusunan laporan keuangan yang akuntabel pada pelaku usaha UMKM yang dilakukan pada Balai Desa Jambu, Kecamatan Lenteng. Pelaksanaan kegiatan tersebut juga sangat berjalan baik dan lancar. Pada proses pelatihan tersebut, peserta yang mengikuti adalah beberapa owner atau pembantu owner dari unit-unit usaha (UMKM) desa Jambu, dimana mereka sangat memilik antusiasme dalam mengukutinya, karena pada saat ini laporan keuangan UMKM sangat dibutuhkan bagi para pelaku usaha tersebut karena untuk memperoleh suatu pinjaman lunak, maka usaha tersebut mampu membuat dan memenuhi, sehingga para pelaku usaha UMKM yang belum memiliki surat hak tanah usaha tersebut juga dapat ditindak lanjuti sekaligus oleh dinas terkait.

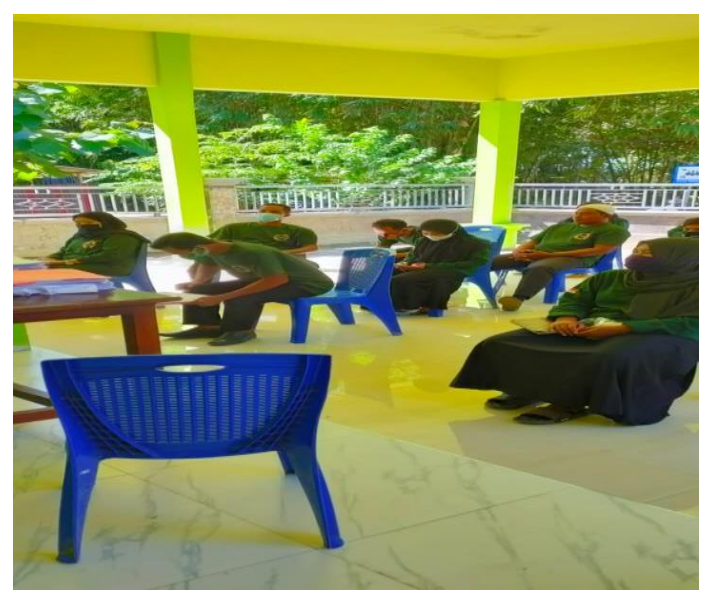

Gambar 1. Proses mengikuti pemberian materi terkait penyusunan laporan keuangan UMKM

Pada Gambar 1. merupakan hasil dokumentasi terkait dengan para pengabdi melakukan tahap sosialiasi dan pendampingan pada para pelaku usahan yang ada di desa jambu tersebut. Pada kegiatan tersebut juga tim tidak hanya melakukan sosialiasi dan pelatihan secara 
bersamaan namun tim memberikan peluang kepada para pelaku usaha untuk memberikan sosialiasi atau pelatihan secara door to door kepada peserta yang mengikuti pelatihan. Hal tersebut dilakukan agar nantinya para peserta tersebut dapat memahami dan membuat laporan keuangannya. Proses pelatihan pencatatan transaksi serta penyusunan laporan keuangan UMKM dilakukan dengan memberikan penyampaian materi terkait dengan klasifikasi akun serta pencatatan transaksi yang sederhana. Klasifikasi akun yang dilakukan yaitu memberikan pemahaman pos-pos akun yang dikategorikan sebagai asset bagi pelaku usaha, pos akun yang dikategorikan sebagai ekuitas atau modal, bahkan sampai dengan pos akun yang dikategorikan sebagai liabilitas, yakni seperti utang usaha, dan lain sebagainya.

Selain pemateri memberikan materi terkait dengan klasifikasi akun, pemateri juga memberikan ulasan gambaran terkait dengan proses pencatatan secara sederhana. Hal tersebut dilakukan agar pelaku usaha mampu memiliki bekal pengetahuan serta pemahaman yang cukup dengan diberikan materi oleh ketiga pemateri yang kelak dapat membawa harapan bahwasanya para pelaku usaha dapat menyusun laporan keuangannya secara akuntabel dan transparan.

\section{KESIMPULAN}

Pada kegiatan sosialisasi dan pelatihan penyusunan laporan keuangan UMKM di Desa Jambu telah dilaksanakan dengan lancer dan baik. Para pemilik atau perwakilan dari UMKM sangat antusias mengikuti sosialisasi dan pelatihan yang secara door to door dan dibalai desa. Selain itu peserta sangat aktif pada saat sesi berdiskusi oleh pemateri. Adanya sosialisasi serta pelatihan tersebut para peserta sangat memiliki pemahaman terkait dengan proses pencatatan atau dasar akuntansi dalam menyusun suatu laporan keuangan yang baik. Manfaat dari kegiatan tersebut bagi pemilik atau perwakilan dari UMKM di Desa Jambu mampu memberikan pengetahuan serta tanggung jawab atas financial statement tersebut.

\section{UCAPAN TERIMA KASIH}

Penulis mengucapkan terimakasih kepada LPPM Universitas Wiraraja yang telah member dukungan financial terhadap pengabdian ini.

\section{DAFTAR PUSTAKA}

Griffin, Ricki W. \& Ronal J. Ebert. (2007). Bisnis. Edisi Ke-8. Jilid 1. Jakarta: Erlangga.

Rudiantoro, R., \& Siregar, SV. (2012). Kualitas Laporan Keuangan UMKM Serta Prospek Implementasi SAK ETAP. Jurnal Akuntansi Dan Keuangan Indonesia, 9(1), Juni 2012.

Wijayanti, Rita. (2020). Pelatihan Penyusunan Laporan Keuangan Pada Usaha Dagang Sahadewa Batik. The 12th University Research Colloqium 2020 Universitas 'Aisyiyah Surakarta, 112-116

Suryatimur, Kartika.P., Khotijah, Siti A., \& Prasetyanto, Panji.K. (2020). Pelatihan Penyusunan Laporan Keuangan pada BUMDes Desa Balesari. Jurnal Pengabdian Untuk Mu Negeri, 4(2), 242-246 